\title{
Effect of Metformin on Insulin Binding to Receptors in Cultured Human Lymphocytes and Cancer Cells
}

\author{
V.Pezzino, V.Trischitta, F. Purrello and R. Vigneri \\ Cattedra di Endocrinologia e Patologia Costituzionale and Istituto di Patologia Medica I, Università di Catania, Ospedale Garibaldi, \\ Catania, Italy
}

\begin{abstract}
Summary. The effect of the biguanide metformin (dimethylbiguanide) on insulin binding in vitro to IM-9 lymphocytes and MCF-7 human breast cancer cells was studied. Metformin significantly increased insulin binding to both cell types: maximum increment was $47.1 \pm 7.0 \%>$ control in IM-9 and $38.0 \pm 6.1 \%$ in MCF-7 cells. The dose-response curves indicated that the latter cell line was more sensitive to metformin, with a significant effect apparent at a metformin concentration of $7.7 \times 10^{-6} \mathrm{~mol} / \mathrm{l}$, similar to the levels reached in patients treated with this drug. When compared with phenfor$\mathrm{min}$, metformin was less active in increasing insulin binding to
\end{abstract}

cultured cells, the ratio between the two drug responses being similar to that of their therapeutic dosage in patients. Insulin binding increment due to metformin was reversible, was not dependent on new protein synthesis and was evident also in IM-9 lymphocytes that had been down-regulated by pre-incubation with insulin $\left(10^{-7} \mathrm{~mol} / \mathrm{l}\right)$. This effect of metformin on insulin binding to receptors may contribute to the hypoglycaemic effect of this agent in patients.

Key words: Metformin, phenformin, biguanides, insulin, insulin receptor.
Biguanides have been used in many countries for the treatment of Type 2 (non-insulin-dependent) diabetic patients. The mechanism of action of these drugs, however, is not completely understood.

We have recently reported that phenformin (phenethyl-biguanide) increases insulin binding to cultured human breast cancer cells [1] and to lymphocytes [2], and that this effect may contribute to the hypoglycaemic action of the drug. In order to evaluate if other biguanides have a similar effect in increasing insulin binding to its receptors, we have studied the effect of metformin [3-5] on insulin binding in vitro to IM-9 human lymphocytes and MCF-7 human breast cancer cells and have compared these findings with those obtained under the same conditions with phenformin.

\section{Material and Methods}

\section{Cultured Cell Lines}

IM-9 human lymphocytes (a gift of Dr. I. D.Goldfine, Cell Biology Laboratory, Mount Zion Hospital, San Francisco, California, USA) were grown in suspension in tissue culture flasks (Corning) in Eagle's minimal essential medium (MEM) enriched with $10 \%$ fetal calf serum, glutamine $(2 \mathrm{mmol} / \mathrm{l})$ and antibiotics, at $37^{\circ} \mathrm{C}$ in a humidified atmosphere of $5 \% \mathrm{CO}_{2}$ and $95 \%$ air, as described previously [6].
MCF-7 human breast cancer cells were a gift of Dr. M. Lippman (National Institute of Health, Bethesda, Maryland, USA) and were grown in continuous monolayer culture in Falcon tissue culture flasks, using Eagle's MEM with $10 \%$ fetal calf serum, glutamine $(2 \mathrm{mmol} / \mathrm{l})$ and antibiotics, as described previously [1]. Both these cell lines are known to have high affinity insulin receptors $[7,8]$. In addition, MCF-7 cells have a sensitive biological responsiveness to insulin [9].

\section{Materials}

Metformin (N, N-dimethyl-biguanide) was a gift from Spemsa Laboratories, Florence, Italy) and phenformin (N-beta-phenethyl-biguanide) was a gift from Boehringer Biochemia, Milan, Italy. Metformin was studied over the concentration range of $3.8 \times 10^{-6}$ to $1.5 \times 10^{-3}$ $\mathrm{mol} / \mathrm{l}$ and phenformin over the range $5 \times 10^{-7}$ to $10^{-3} \mathrm{~mol} / \mathrm{l}$. Porcine insulin $(16 \mathrm{U} / \mathrm{mg})$, cycloheximide and $\mathrm{N}$-2-hydroxyethyl-piperazine ethane sulphonic acid (Hepes) buffer were purchased from Sigma Chemicals, St. Louis, USA. Insulin was labelled with ${ }^{125}$ I (Radiochemical Centre, Amersham, Bucks, UK) by a modified chloramine-T method to a specific activity of $95-140 \mu \mathrm{Ci} / \mu \mathrm{g}$, as described previously [10]. Eagle's MEM (comprising standard solutions of essential aminoacids and vitamins with Earle's salts) was purchased from Labtek, Milan, Italy. All other chemicals and reagents were of analytical grade.

\section{Binding Studies}

IM-9 Cultured Lymphocytes. IM-9 lymphocytes were collected by centrifugation at $600 \times \mathrm{g}$ for $10 \mathrm{~min}$ at room temperature and resuspended in fresh medium enriched with $20 \mathrm{mmol} / \mathrm{l} \mathrm{Hepes}(\mathrm{pH} 7.4)$ at 


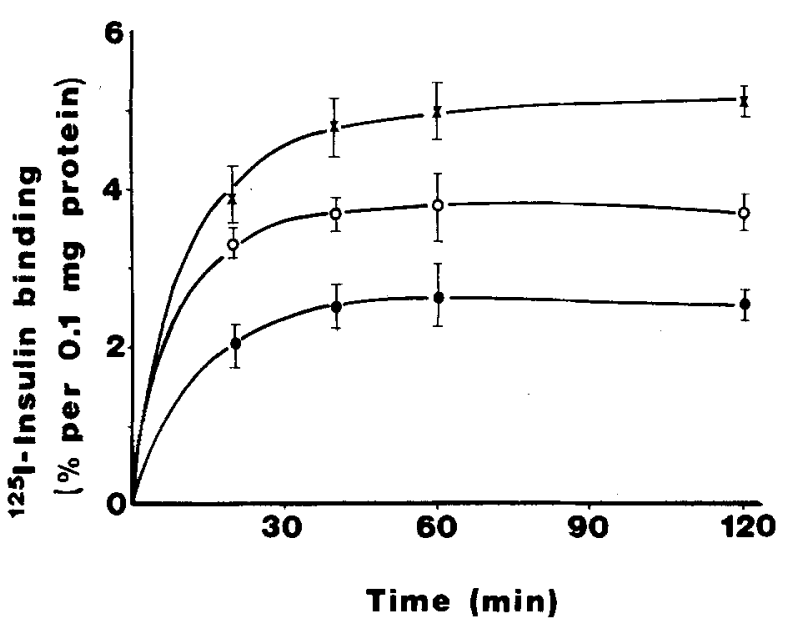

Fig. 1. Time course of specific ${ }^{125} \mathrm{I}$-insulin binding to control IM-9 lymphocytes $(-)$ ) and to metformin $(\mathrm{O}-\mathrm{O})$ or phenformin $(x-x)$ treated IM-9 cells. Cells were pre-incubated with drugs for $24 \mathrm{~h}$ at $37^{\circ} \mathrm{C}$. Time points represent mean \pm SEM of ten separate experiments for metformin $\left(3.8 \times 10^{-4} \mathrm{~mol} / 1\right)$ and of six experiments for phenformin $\left(2 \times 10^{-5} \mathrm{~mol} / \mathrm{l}\right)$ and are expressed as percentage binding of total substrate per $0.1 \mathrm{mg}$ protein
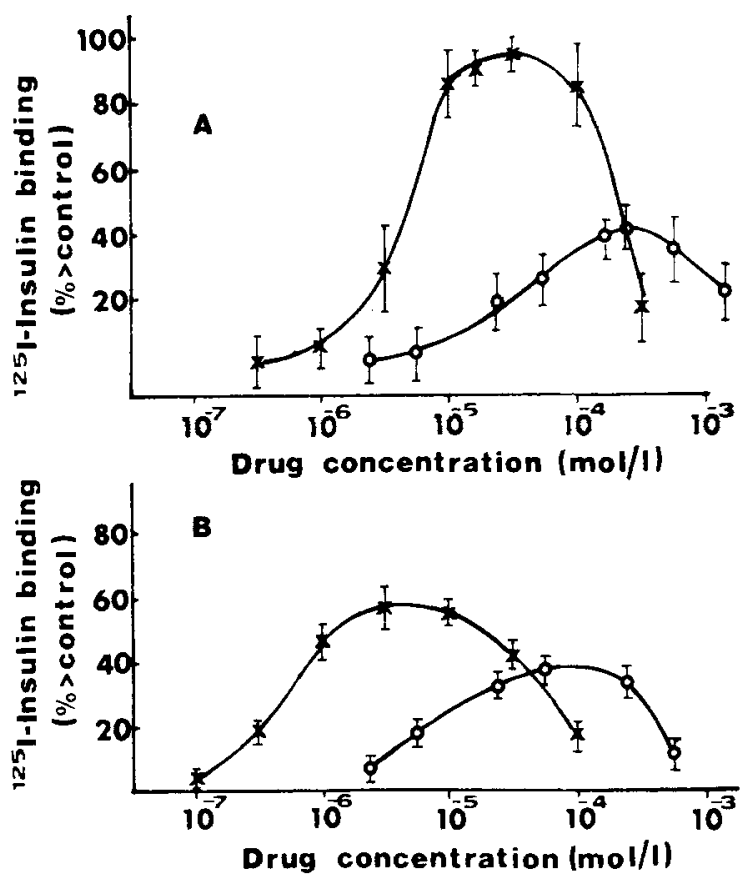

Fig.2. Dose-response of specific ${ }^{125}$ I-insulin binding to IM-9 lymphocytes $(A)$ and MCF-7 cells $(B)$ in the presence of increasing concentrations of phenformin $(x-x)$ and metformin $(O-O)$. Cells were pre-incubated with drugs for $24 \mathrm{~h}$ at $37^{\circ} \mathrm{C}$. Each point represents mean \pm SEM of at least three separate experiments

a cell concentration of approximately $0.8 \times 10^{6}$ cells $/ \mathrm{ml}$ in tissue culture flasks. The drugs were added and the cells were placed in an incubator at $37^{\circ} \mathrm{C}$. After $24 \mathrm{~h}$ the cells were placed in fresh (drug-free) medium at $24^{\circ} \mathrm{C}$, and ${ }^{125} \mathrm{I}$-insulin $\left(4 \times 10^{-11} \mathrm{~mol} / \mathrm{l}\right)$ was added in the absence, and presence of $1.7 \times 10^{-5} \mathrm{~mol} / \mathrm{I}$ porcine insulin. After 20 , 40,60 and $120 \mathrm{~min}$, bound insulin was separated from free hormone by centrifuging triplicate $400 \mu \mathrm{l}$ samples in a Beckman Microfuge for $3 \mathrm{~min}$. The supernatants were collected for insulin degradation studies. The pellets were then washed once with ice cold saline and finally the tips of the microfuge tubes were excised and counted in an automatic gamma-counter.

MCF-7 Human Breast Cancer Cells. MCF-7 cells were plated in Falcon tissue culture flasks and grown for $3-4$ days until they reached a semi-confluence state. The medium was then replaced and the drugs were added. After $24 \mathrm{~h}$ the cells were harvested following the procedure of Osborne et al. [8]. The cells were then resuspended in a drugfree binding buffer $(50 \mathrm{mmol} / 1 \mathrm{Hepes}, 120 \mathrm{mmol} / \mathrm{I} \mathrm{NaCl}, 1.2 \mathrm{mmol} / 1$ $\mathrm{MgSO}_{4}, 2.5 \mathrm{mmol} / 1 \mathrm{KCl}, 15 \mathrm{mmol} / 1 \mathrm{CH}_{3} \mathrm{COONa}, 1 \mathrm{mmol} / 1$ EDTA and $1 \%$ bovine serum albumin, $\mathrm{pH} 7.7$ ) to a final concentration of approximately $1 \times 10^{6}$ cells $/ \mathrm{ml}$ and incubated with ${ }^{125} \mathrm{I}$-insulin $(4 \times$ $10^{-11} \mathrm{~mol} / \mathrm{I}$ ) in the presence and absence of $1.7 \times 10^{-5} \mathrm{~mol} / 1$ insulin at $23{ }^{\circ} \mathrm{C}$. After 3 and $6 \mathrm{~h}$, triplicate $200 \mu \mathrm{l}$ aliquots of cell suspensions were centrifuged in a Beckman Microfuge and the pellets were washed, collected and counted following the same technique as for the IM-9 cells.

In all studies, ${ }^{125}$ I-insulin bound in the presence of excess unlabelled insulin was subtracted from binding levels in the presence of tracer alone to yield specific binding values.

Insulin binding was always normalized to protein content, which was measured by the method of Lowry et al. [11], using bovine serum albumin as a standard. Protein values per $10^{6}$ IM-9 or MCF-7 cells were approximately 0.15 and $0.18 \mathrm{mg}$ respectively. ${ }^{125} \mathrm{I}$-insulin degradation during each experiment was determined in the supernatants by $10 \%$ trichloroacetic acid precipitation.

Cell viability, measured by Trypan blue exclusion at the end of each binding study, was always $>95 \%$.

\section{Results}

\section{IM-9 Lymphocytes}

Time courses of insulin binding to control IM-9 cells and to cells pre-incubated with both metformin and phenformin showed similarly shaped binding curves: both drugs induced an increased binding at all the time points assayed (Fig. 1). Non-specific insulin binding was $3 \%-5 \%$ of the total binding and was not affected by the drugs.

When IM-9 lymphocytes were pre-incubated $24 \mathrm{~h}$ with increasing concentrations of metformin, an enhanced insulin binding to these cells was detectable at a metformin concentration of $3.8 \times 10^{-5} \mathrm{ml} / 1$, and a maximal effect at $3.8 \times 10^{-4} \mathrm{~mol} / \mathrm{l}$ (Fig. 2). Higher metformin concentrations induced decreased insulin binding, probably due to the cytotoxic effect of the drug which increased cell destruction under these experimental conditions. Maximum insulin binding increment in the presence of metformin was $47.1 \pm 7.0 \%>$ control (mean \pm SEM of ten separate experiments; $p$ $<0.01)$.

Under similar conditions, phenformin was also effective in increasing insulin binding: a significant effect was seen at $5 \times 10^{-6} \mathrm{~mol} / 1$ and maximal effect in the range $2 \times 10^{-5}$ to $10^{-4} \mathrm{~mol} / 1$. Phenformin concentrations higher than $10^{-4} \mathrm{~mol} / 1$ were toxic under the experimental conditions and caused a sharp decrease of insulin binding (Fig. 2). Maximal increment of binding in the presence of phenformin was $95.0 \pm 12.3 \%>$ control cells (six separate experiments, $p<0.01$ ). 
Scatchard analysis indicated than in IM-9 lymphocytes metformin, as well as phenformin, increases insulin binding mainly by increasing the receptor affinity. Our studies, however, cannot exclude an effect of these drugs also on the number of the insulin receptors.

\section{MCF-7 Human Breast Cancer Cells}

Both metformin and phenformin increased insulin binding to MCF-7 cells but the effect was less than that observed in the IM-9 lymphocytes. Neither drug affected non-specific insulin binding which was $12 \%-20 \%$ of total binding. Maximum insulin binding increment was $38.0 \pm 6.1 \%>$ control for metformin and $59.1 \pm 6.9 \%$ $>$ control for phenformin (mean \pm SEM of seven separate experiments, $p<0.05$ for both drugs). In MCF7 cells, the dose response curves of both metformin and phenformin were displaced to the left of the corresponding curves for IM-9 lymphocytes with maximal effects at $7.7 \times 10^{-5} \mathrm{~mol} / 1$ for metformin and $5 \times 10^{-6}$ $\mathrm{mol} / \mathrm{l}$ for phenformin (Fig. 2).

Table 1. Reversibility of metformin-induced increase in ${ }^{125} \mathrm{I}$-insulin binding to IM-9 lymphocytes.

\begin{tabular}{lll}
\hline & \multicolumn{2}{l}{$\begin{array}{l}\text { Percentage of bound }{ }^{125} \text { I-insulin per } 0.1 \mathrm{mg} \\
\text { protein }\end{array}$} \\
\cline { 2 - 3 } & $\begin{array}{l}\text { 24-h } \\
\text { incubation } \\
\text { in medium }\end{array}$ & $\begin{array}{l}\text { Subsequent 2-h washing and } \\
\text { 3-h incubation in fresh } \\
\text { medium without metformin }\end{array}$ \\
\hline $\begin{array}{l}\text { Control } \\
\text { Metformin }\end{array}$ & $2.14 \pm 0.13$ & $2.06 \pm 0.20$. \\
$\left(3.8 \times 10^{-4} \mathrm{~mol} / \mathrm{l}\right)$ & $3.15 \pm 0.25$ & $2.21 \pm 0.10$
\end{tabular}

Binding experiments were carried out $3 \mathrm{~h}$ after extensive washing. Values represent mean \pm SEM of five separate experiments

\section{Other Studies}

As shown, the results obtained with the two cell lines are essentially similar. MCF-7 cells were more sensitive than IM-9 cells to low drug concentrations, but under optimal conditions both biguanides induced a greater effect in IM-9 lymphocytes than MCF-7 cells.

${ }^{125} \mathrm{I}$-insulin degrading activity was much higher in MCF- 7 than in IM-9 cells ( $40 \%$ versus $5 \%$ of the added tracer after 3 and $2 \mathrm{~h}$ incubation, respectively). Biguanides did not influence degradation in either cell system. Since IM-9 cells are more easy to handle and have a low insulin degrading activity, the majority of studies were subsequently carried out with these lymphocytes. The effect of metformin on insulin receptors was reversible: when metformin-treated IM-9 cells were washed to remove the drug, and a binding study then performed after $3 \mathrm{~h}$ incubation in fresh medium, a decrease of the metformin-induced insulin binding level was observed (Table 1). To establish the time needed for biguanides to increase insulin binding to IM-9 lymphocytes, we stud-

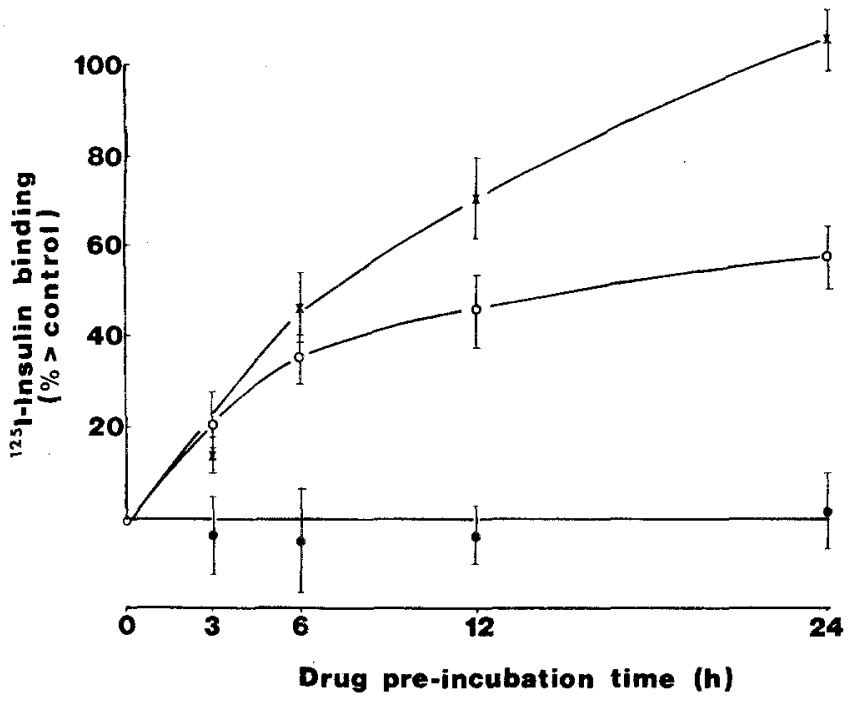

Fig.3. Effect of pre-incubation time on the subsequent ${ }^{125} \mathrm{I}$-insulin binding to control (-O) and metformin $\left(\mathrm{O}-\mathrm{O}, 3.8 \times 10^{-4}\right.$ $\mathrm{mol} / \mathrm{l})$, or phenformin $\left(\times-\times, 2.5 \times 10^{-5} \mathrm{~mol} / \mathrm{l}\right)$ treated IM-9 lymphocytes. Binding was measured after $2 \mathrm{~h}$ incubation with labelled insulin. Each point represents mean \pm SEM of at least three separate experiments

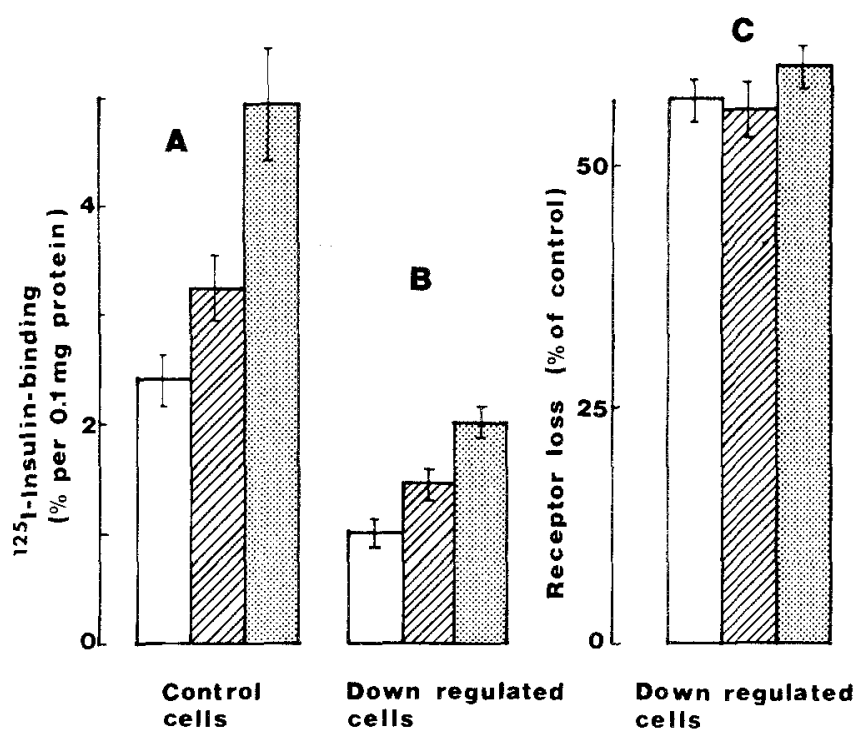

Fig.4. Effect of metformin ( $\left.囚 3.8 \times 10^{-4} \mathrm{~mol} / \mathrm{l}\right)$ and phenformin $(B$ $2 \times 10^{-5} \mathrm{~mol} / \mathrm{l}$ ) on subsequent ${ }^{125}$ I-insulin binding to IM-9 lymphocytes. Cells were pre-incubated with drugs or with media alone ( $\square$ for $24 \mathrm{~h}$ at $37^{\circ} \mathrm{C}$ in the absence (panel $A$ ) and in the presence (panel $B$ ) of porcine insulin $\left(10^{-7} \mathrm{~mol} / \mathrm{l}\right)$. Data represent mean \pm SEM of four separate experiments. The percentage receptor loss in down regulated cells versus cells incubated in insulin-free media is shown to be not significantly affected by the drugs (panel $C$ )

ied different pre-incubation times of cells with these hypoglycaemic agents. Under the experimental conditions a significant effect of metformin $\left(3.8 \times 10^{-4} \mathrm{~mol} / \mathrm{l}\right)$ and phenformin $\left(2.5 \times 10^{-5} \mathrm{~mol} / \mathrm{l}\right)$ was seen only after $3 \mathrm{~h}$ of pre-incubation. Thereafter, the insulin binding increase followed a different pattern for the two biguanides, with a more marked increase in the presence of phenformin (Fig. 3). 
The effect of cycloheximide, an inhibitor of protein synthesis, was tested to investigate whether metformin increased insulin binding to IM-9 cells through an increase in the synthesis of insulin receptors.

Cycloheximide had no significant effect on the increase of insulin binding to IM-9 cells induced by metformin $\left(3.8 \times 10^{-4} \mathrm{~mol} / 1\right)$. A similar increment of binding, in fact, was seen in the presence of $5 \times 10^{-5} \mathrm{~mol} / 1$ cycloheximide, a concentration able to inhibit $>90 \%$ of protein synthesis and cell growth.

Metformin $\left(3.8 \times 10^{-4} \mathrm{~mol} / \mathrm{l}\right)$ was also able to induce a significant rise of insulin binding in down-regulated IM-9 lymphocytes. In fact, a similar percentage increase of insulin binding to its receptors was observed in the presence of metformin when control IM-9 cells were compared to IM-9 cells pre-incubated with insulin $\left(10^{-7} \mathrm{~mol} / \mathrm{l}\right)$ for $24 \mathrm{~h}$ and then extensively washed before the binding study (Fig.4).

\section{Discussion}

We reported previously that the biguanide phenformin increases insulin binding to cultured cells in vitro. The present data extends this observation to another biguanide, metformin. In addition, we have now tested two different human cultured cell lines (MCF-7 breast cancer and IM-9 lymphocytes) and both biguanides were effective in increasing insulin binding to both cell types. Since we observed a similar effect of phenformin also in cultured rat hepatoma cells [2], the experimental data strongly support two conclusions: a) increased insulin binding to its receptor may be a general property of different biguanides; b) the effect of biguanides can be observed in different tissues of different species. The effectiveness of biguanides, however, varies in different cell lines: our results indicate that both metformin and phenformin were active at a lower concentration in MCF-7 cells than in IM-9 lymphocytes. In the former cell line, concentrations as low as $5 \times 10^{-7} \mathrm{~mol} / 1$ of phenformin and $7.7 \times 10^{-6} \mathrm{~mol} / 1$ of metformin significantly increased specific insulin binding. These concentrations are in the ranges of those reached in diabetic patients treated with these biguanides $[12,13]$. We have preliminary evidence that, in vivo, biguanide administration also increases insulin binding to monocytes of patients treated with these drugs (unpublished data). Furthermore, Holle et al. [15] have recently reported an increased insulin binding to erythrocytes of patients treated with metformin. Both in vitro and in vivo observations, therefore, support the theory that part of the hypoglycaemic action of biguanides is due to a potentiation of the insulin action consequent to an increased binding of the hormone to its peripheral receptors.

When the two biguanides were compared under the same experimental conditions, phenformin appeared to be more active than metformin. In both MCF-7 and IM-9 cells, in fact, the minimal and maximal effective- ness of phenformin concentrations were displaced one order of magnitude in the dose response curves compared to corresponding metformin values (Fig. 2). This difference roughly parallels the difference in the therapeutic doses of the two drugs. Under optimal concentrations, however, phenformin induced a more marked increase of insulin binding than metformin to both IM-9 and MCF-7 cells. This difference between the two drugs probably reflects the more prolonged effect of phenformin: a prompt increase of insulin binding and no significant difference between phenformin and metformin was seen up to $6 \mathrm{~h}$ of pre-incubation (Fig. 3). Thereafter, metformin induced only a moderate increase of insulin binding but the rise induced by phenformin, on the contrary, persisted and the difference between the two biguanides was substantial after $24 \mathrm{~h}$ preincubation.

The biochemical basis of the mechanism of action of biguanides in enhancing insulin binding to its receptors is unknown. The present data with cycloheximide, an inhibitor of protein synthesis, indicate that metformin does not initiate synthesis of new insulin receptors. Shuttling of receptors from the cell interior to the surface, unmasking of surface receptors or changes in the conformation and aggregation of receptors are all possible mechanisms.

Metformin is able to increase insulin binding even in 'down-regulated' IM-9 cells (Fig.4). This binding could be interpreted as partial inhibition by metformin on down regulation of insulin receptors by insulin itself. Percentage receptor loss, however, is similar in metformin and phenformin-treated IM-9 cells when compared with control cells (Fig. 4). Therefore, it is likely that receptor loss due to 'down regulation' and increased binding due to biguanides are independent phenomena.

An alternative possibility that deserves further investigation is that biguanides influence insulin binding indirectly, as a consequence of the changes they are known to induce in many cellular metabolic pathways. Biguanides are known to inhibit the mytochondrial respiratory chain [16], to modify the Krebs cycle and to deplete the cellular energy substrates [17], and to increase the glycolytic pathway and lactate production $[18,19]$. One or more of these metabolic events might be the direct or indirect signal for the cell to increase insulin receptor affinity and concentration, acting thereby as a mediator of this action of the biguanides.

\section{References}

1. Cohen D, Pezzino V, Vigneri R, Avola R, Polosa P (1980) Phenformin increases insulin binding to human cultured breast cancer cells. Diabetes 29: 329-331

2. Vigneri R, Pezzino V, Wong KY, Goldfine ID (1982) Comparison of biguanides and sulphonylureas: effect on insulin receptors in vitro. J Clin Endocrinol Metab 54: 95-100

3. Alberti KGMN, Nattrass M (1977) Lactic acidosis. Lancet II: $25-29$ 
4. Luft D, Schmulling RM, Eggstein M (1978) Lactic acidosis in biguanide-treated diabetes. A review of 330 cases. Diabetologia 14: $75-78$

5. Sirtori CR, Tremoli E, Sirtori M, Conti F, Paoletti R (1977) Treatment of hypertriglyceridemia with metformin. Effectiveness and analysis of results. Atherosclerosis 26:583-592

6. Goldfine ID, Smith GJ, Wong KY, Jones AL (1977) Cellular untake and nuclear binding of insulin in human cultured lymphocytes: evidence for potential intracellular sites of insulin action. Proc Natl Acad Sci USA 74: 1368-1372

7. Gavin GR, Roth J, Neville DM, De Meyts P, Buell DN (1973) Insulin-dependent regulation of insulin receptor concentrations: a direct demonstration in cell culture. Proc Natl Acad Sci USA 71: $84-88$

8. Osborne CK, Monaco ME, Lippman ME, Kahn CR (1978) Correlation among insulin binding, degradation, and biological activity in human breast cancer cells in long-term tissue culture. Cancer Res 38: 94-102

9. Osborne CK, Bolan G, Monaco ME, Lippman ME (1976) Hormone responsive human breast cancer in long-term tissue culture: effect of insulin. Proc Natl Acad Sci USA 73: 4536-4540

10. Goldfine ID, Smith GJ (1976) Binding of insulin to isolated nuclei. Proc Natl Acad Sci USA 73: 1427-1431

11. Lowry OH, Rosebrough NJ, Farr AL, Randall RJ (1951) Protein measurement with the folin phenol reagent. J Biol Chem 193: 265-275

12. Vigneri R, Pezzino V, Iwamoto $Y$, Wong KY, Polosa P, Goldfine ID (1982) In vitro effects of oral hypoglycaemic agents on the binding of ${ }^{125}$ I-insulin to cultured cells. In: Andreani D, De Pirro R, Lauro R (eds) Insulin receptors. Academic Press, New York, pp 595-599
13. Catellier C, Fraser E, Ayatte-FerronL, Savoie JY (1977) Blood levels of phenformin following a customary therapeutic dose. Union Med Can 106: 323-326

14. Mehnert H (1969) Pharmacokinetics of blood glucose lowering biguanide derivatives. Acta Diabetol Lat 6: 137-142

15. Holle A, Dreyer M, Kuhnau J, Mangels W, Maack P, Siemers U, Rudiger HW (1982) Metformin increases the number of insulin receptors in human erythrocytes. In: Andreani D, De Pirro R, Lauro R (eds) Insulin receptors. Academic Press, New York, pp 601-605

16. Towes CJ, Kyner JL, Cannon JJ, Cahill JF Jr (1971) Effect of phenformin on mitochondrial transport of reducing equivalents in perfused rat liver. Fed Proc 30: 257 (Abstract)

17. Muntoni S (1974) Inhibition of fatty acid oxidation by biguanides: implication for metabolic physiopathology. Adv Lip Res 12: 311-377

18. Hermann LS (1973) Biguanides and lactate metabolism: a review. Dan Med Bull 20: 65-79

19. Kreisberg RA, Pennington LF, Bashell BR (1970) Lactate turnover and gluconeogenesis in obesity. Effect of phenformin. Diabetes 19: 64-69

Received: 3 June 1981

and in revised form: 22 April 1982

V.Pezzino, M.D.

Cattedra Endocrinologia

via Ofelia, 35

I-95124 Catania, Italy 